\title{
anemon
}

Muş Alparslan Üniversitesi Sosyal Bilimler Dergisi

Journal of Social Sciences of Muş Alparslan University

Yıl/Year: 2016 • Cilt/Volume: 4 • Sayı/Number: 2

ISSN: 2147-7655 • e-ISSN: 2149-4622

ÖZGÜN ARASSTIRMA • ORIGINAL ARTICLE

\section{Makroekonomik Belirsizlik ve Risk Altında Yatırım Kararları: Türkiye Örneği ${ }^{\mathrm{a}}$}

\author{
Celil AYDIN ${ }^{1, b}$, Fatma Gündoğdu ODABAŞIOĞLU ${ }^{2}$
}

${ }^{1}$ Yrd. Doç. Dr., Muş Alparslan Üniversitesi, İ̈BF, İktisat Bölümü - Muş/ Türkiye
${ }^{2}$ Yrd. Doç. Dr., Atatürk Üniversitesi, İIBF, İktisat Bölümü - Erzurum / Türkiye

Başvuru tarihi: 17 Mayıs 2016 Düzeltme tarihi: 25 Temmuz 2016 Kabul tarihi: 12 Ağustos 2016

Öz

Bu çalışmada belirsizlik ve risk faktörlerinin, Türkiye'de reel sektörde faaliyet gösteren firmaların sabit sermaye ve finansal yatırım kararları üzerindeki etkileri 2003-2012 dönemi itibariyle araştırılmıştır. Bu amaçla çalışmada, ARCH-GARCH yöntemi ile elde edilen enflasyon, döviz kuru ve büyüme hızı belirsizlikleri ile ekonomik, politik, finansal ve ülke risk göstergeleri kullanılmıştır. $\mathrm{Bu}$ faktörlerin yatırımlar üzerindeki etkileri dinamik panel veri analiz yönteminden hareketle portföy seçim modeli kullanılarak oluşturulan yatırım denklemi çerçevesinde değerlendirilmiştir. Araştırma sonuçlarına göre risk faktörleri ve belirsizliklerin yatırım kararları üzerinde negatif ve anlamlı bir etkisi olduğu tespit edilmiştir.

\section{Anahtar Kelimeler}

Belirsizlik, Risk, Yatırım Kararları, Dinamik Panel Veri Analizi

\footnotetext{
a Bu çalışma, Atatürk Üniversitesi Sosyal Bilimler Enstitüsü tarafından kabul edilen "Makroekonomik belirsizlik ve risk altında yatırım kararları: BRICS ülkeleri ve Türkiye örneği"başlıklı doktora tezinden türetilmiş ve Saraybosna'da düzenlenen Second Sarajevo International Conference of Social Sciences isimli konferansta bildiri olarak sunulmuştur.

b Sorumlu Yazar/Correspoding Author: Muş Alparslan Üniversitesi Kampüsü, İktisadi ve İdari Bilimler Fakültesi, İktisat Bölümü, 49250, Muş / Türkiye.

e-posta: celil.aydin@atauni.edu.tr 


\title{
Investment Decisions under Macroeconomic Uncertainty and Risk: The Case of Turkey
}

\begin{abstract}
In this study, the impacts of uncertainty and risk factors on fixed asset and financial investment decisions of the firms in real sector in Turkey have been investigated for the period of 2003-2012. For this aim, inflation, exchange and growth rate uncertainties having been obtained by ARCHGARCH method and economic, political, financial and country risk indicators have been used in this study. Their impact on investment is assessed by using investment equation that is generated by portfolio choice model, in accordance with the dynamic panel data analysis. The results show that risk factors and uncertainty have a negative and significant impact on investment decisions.
\end{abstract}

\section{Keywords}

Uncertainty, Risk, Investment Decisions, Dynamic Panel Data Analysis

\section{GİRIŞ}

Geleceğin bilinmemesi, yatırım kararı verme ya da yatırım yapma aşamasında olan yatırımcıların kararlarında hata yapmalarına sebep olabilmektedir. $\mathrm{Bu}$ nedenle yatırımcılar, sahip oldukları bilgiyi kullanarak yatırımlardan elde edecekleri kârı en iyi şekilde tahmin etmeye çalışmakta ve bu tahmine uygun olarak da beklentiler oluşturmaktadırlar. Ekonominin ve siyasi dengelerin sürekli olarak değişmesi, bu aşamada yatırımcıların karşısına iki önemli sorunu çıkarmaktadır; "belirsizlik" ve "risk".

Genel olarak, belirsizlik ve risk kavramları günlük hayatta birbiri yerine kullanılmasına rağmen, bu kavramlar farklı anlamlara sahiptir ve aralarında bazı farklılıklar bulunmaktadır. Belirsizlik ve risk kavramları arasındaki en temel ayırım, yatırımcıların yatırımlardan elde edilecek kârla ilgili olası sonuçlar hakkında iyi tanımlanmış olasılıklara sahip olup olmadıklarına göre yapılmaktadır (LeRoy ve Singell, 1987: 394 395). $\mathrm{Bu}$ durum, belirsizlik ve risk kavramlarının yatırım kararlarını farklı şekilde etkilediğinin bir göstergesi olabileceğinden dolayı, bu iki kavramın yatırımlar üzerindeki etkilerinin ayrı ayrı incelenmesi gerekmektedir.

Belirsizlik ve risk koşulları, yatırımcıların geleceğe ilişkin yatırım kararlarını olumsuz etkilemektedir. Artan belirsizlik ve risk ortamı yatırımcıların yatırımlarını ertelemelerine neden olmaktadır. Bu durum, ekonominin tümünde etkili olan bir yavaşlamaya yol açabilmektedir (Arslan vd., 2012: 2). Belirsizlik ve riskin yatırımlar üzerindeki olumsuz etkisini ve bu etkinin büyüklügünü belirleyen, uygulanan makroekonomik politikalar, sermaye ve para piyasalarının durumu, dışa açıklık, siyasi ve finansal istikrar gibi birçok faktör bulunmaktadır (Pradhan vd., 2004: 2162). Bu bağlamda, belirsizlik ve riski 
oluşturan faktörlerin belirlenmesi ve bu faktörlerin yatırımlar üzerindeki etkilerinin saptanması önem arz etmektedir.

Belirsizlik ve risk faktörlerinin firmaların yatırım kararları üzerindeki etkilerini inceleyen literatürde tam bir fikir birliğinin olmadığı görülmektedir. Literatürde yer alan bazı çalışmalar belirsizlik ve risk faktörlerinin firmaların yatırımlarını artırabileceğini ileri sürerken, diğer çalışmalar ise belirsizlik ve risk altında firmaların yatırımlarının azalacağ fikrini savunmaktadır. Konu ile ilgili literatür incelendiğinde; belirsizlik ve risk faktörlerinin firmaların yatırım kararları üzerinde herhangi bir etkisinin bulunmadığ (Aizenman ve Marion, 1993; Günçavdı ve Mckay, 2003; Sile, 2003; Demir, 2009a), belirsizlik ve risk faktörlerinin firmaların yatırım kararlarını pozitif yönde (Özman, 1996; Karapınar, 2008; Le, 2004; Campos ve Nugent, 2003) yada negatif yönde (Alesina ve Perotti, 1996; Özman, 1996; Sile, 2003; Le, 2004; Luintel ve Mavrotas, 2005; Özçiçek, 2007; Karapınar, 2008; Demir, 2009a; Demir, 2009b; Koç ve Değer, 2010; Arestis vd., 2012; Escaleras ve Kottaridi, 2014) etkilediğine dair geniş bir literatür olduğu görülmektedir.

Bu çalışmanın amacı, Türkiye'de reel sektörde faaliyet gösteren firmaların sabit sermaye ve finansal yatırım kararlarına etki eden faktörleri, belirsizlik ve risk koşullarını göz önünde bulundurarak incelemektir. Bu amaç doğrultusunda, çalışmada ilk olarak modern yatırım modellerinden portföy seçim modeli hakkında teorik bilgi verilecektir. Ardından modellerde kullanılmak üzere, firmaların sabit sermaye ve finansal yatırımları belirleyen belirsizlik faktörleri için enflasyon, döviz kuru ve büyüme hızı belirsizlikleri ARCHGARCH yöntemleri kullanılarak tahmin edilecektir. Ayrıca modelde risk faktörleri olarak ekonomik, politik, finansal ve ülke riski olmak üzere dört farklı endeks değeri kullanılacaktır. Devamında, belirsizlik ve risk koşullarında, firmaların sabit sermaye ve finansal yatırım kararlarını belirleyen faktörler, yatırımların dinamik boyutunu hesaba katan dinamik panel veri analiz yöntemlerinden fark genelleştirilmiş momentler metodu (fark GMM ) ile tespit edilecek ve sonuç bölümünde ise yatırımları belirleyen belirsizlik ve risk faktörlerine ilişkin ekonometrik tahminlerden elde edilen bulgular yorumlanacaktır.

\section{TEORIKK MODEL}

$\mathrm{Bu}$ çalışmada belirsizlik ve risk koşullarında firmaların yatırım kararlarını etkileyen faktörlerin belirlenmesi amacıyla portföy seçim modeli kullanılmıştır. Portföy seçim modelinin teorik yapısı ise Tobin (1965), Huang ve Litzenberger (1988), Tornell (1990), Le ve Zak (2006) ile Demir (2009b)'in çalışmalarından yararlanılarak oluşturulmuştur. $\mathrm{Bu}$ modele göre gelişmekte olan bir ülkede sınırsız sayıda ve özdeş yatırımcı yer almaktadır. Yatırımcılar sahip oldukları serveti kendi ülkelerinde ya da diğer ülkelerde bir dönem boyunca sabit (makine vb.) ve finansal (Hazine Bonosu vb.) varlıklara yatırım yapmak için ayırmakta ve dönem sonunda bu varlıklardan elde ettikleri getiriyi harcamaktadırlar. Sabit varlık yatırımları riskli ve yüksek getiri oranına sahipken finansal varlık yatırımları risksiz fakat zaman içinde değişmeyen düşük bir getiri oranına sahiptir. Yatırımcılar yatırım kararlarını verirken en yüksek getiri oranına sahip sabit ve finansal varlık sepetini oluşturmaya çalışmaktadırlar. Yatırımcılar bu sepetteki varlık dağılımının nasıl olacağına portföy seçim modelini kullanarak karar vermektedirler. Modeli 
basitleştirmek adına yatırımcıların sahip oldukları varlıklar ile sadece kendi ülkelerinde yatırım yaptıkları, yatırımların tek bir pazara yapıldığı, ülkede yalnızca homojen bir malın olduğu, işgücü gelirlerinin göz ardı edildiği, ülke nüfusunun hareketsiz, normalize edilmiş ve büyüme hızının sıfır olduğu gibi bazı temel varsayımlar yapılmıştır.

$t$ zamanında yatırımcıların sabit varlık yatırımları $I_{t}^{k}$ ve getiri oranı ise $r_{t}^{k}$ ile gösterilmiştir. $r_{t}^{k}$ 'nın $\mu$ ortalama ve $\sigma^{2}$ varyans ile normal dağılıma sahiptir, $r_{t}^{k} \sim N(\mu, \sigma)^{2}$. Yatırımcılar aynı zamanda risksiz fakat zaman içinde değişmeyen düşük bir getiri oranına sahip finansal varlıklara da yatırım yapabilirler. $I_{t}^{f} t$ zamanında karar birimlerinin finansal varlık yatırımları olarak gösterilmiş ve getiri oranı ise $r_{t}^{f}$ ile gösterilmiştir. Bu iki yatırım türü, yatırımcılar tarafından $t$ başlangıç zamanında ve karar birimlerinin sahip olduğu ilk servet $\left(W_{0}\right)$ düzeyi ile yapılmıştır. Temsili bir yatırımcı için $t=0$ zamanında yapılan sabit ve finansal varlık yatırımı denklem (1)'deki gibi ifade edilmiştir;

$W_{0}=I_{t}^{k}+I_{t}^{f}$

ve bu eşitlik denklem (2)'deki gibi düzenlenmiştir;

$I_{t}^{f}=W_{0}-I_{t}^{k}$

$t$ zamanında yatırımcı tarafından yapılan sabit ve finansal varlık yatırımlarından elde edilen getiri sonucu oluşan servet denklem (3)'te gösterilmiştir;

$W_{t}=W_{0}\left(1+r^{f}\right)+I_{t}^{k}\left(r_{t}^{k}-r^{f}\right)$

Bir yatırımcı gerçekleştirmiş olduğu yatırımlarda ifade (4)’teki kısıtı kullanarak beklenen faydasını maksimize etmeye çalışmaktadır.

${ }_{W_{t}}^{\operatorname{Max}} E \sum_{t=0}^{\infty} \beta^{t} U\left(W_{t}\right)$

$U(W)$ fayda fonksiyonu kesinlikle artan, sürekli ve içbükeydir. $U^{\prime}\left(W_{t}\right)$ ve $\left(r_{t}^{k}-r^{f}\right)^{\prime}$ nin normal dağılıma sahip olduğu varsayımı altında ve Stein lemma's ${ }^{1}$ kullanılarak elde edilen optimal varlık dağılımı denklem (5)'teki gibi ifade edilmektedir.

$I_{t}^{k *}=\frac{-E\left[U^{\prime}\left(W_{t}\right)\right] E\left[\left(r_{t}^{k}-r^{f}\right)\right]}{E\left[U^{\prime \prime}\left(W_{t}\right)\right] \operatorname{var}\left(r_{t}^{k}\right)}=\frac{E\left[\left(r_{t}^{k}-r^{f}\right)\right]}{\delta \operatorname{var}\left(r_{t}^{k}\right)}$

Denklem (5)'te $I_{t}^{k *}$ sabit varlık yatırımlarının Gayri Safi Yurtiçi Hâsıla içindeki payını gösterirken, $\operatorname{var}\left(r_{t}^{k}\right)$ sabit varlık yatırımları getiri oranı varyansını göstermekte ve belirsizlik ile risk faktörü olarak tanımlanmaktadır. $\delta \equiv-E\left[U^{\prime}\left(W_{t}\right)\right] / U^{\prime \prime}\left(W_{t}\right)$ ise yatırımcıların riskten kaçınma değerini ölçmektedir. Riskten kaçınma değerinin sabit olduğu varsayılmıştır.

Denklem (5)'teki eşitlik sabit varlık yatırımlarının sabit ve finansal varlık yatırım getiri oranları açığı $\left(r_{t}^{k}-r^{f}\right)^{\prime}$ nın artan fonksiyonu, riskten kaçınma değerinin sabit olduğu varsayımı altında belirsizlik ve riskin azalan fonksiyonu olduğunu göstermektedir. Beklenen getiri oranları açığının küçülmesi, sabit varlık yatırımlarını azaltmaktadır. Yatırımcıların riskten kaçınma değeri yükselirse yatırım riski artmakta ve sabit varlık yatırımları azalmaktadır. 
Denklem (5)'teki eşitliğin her iki tarafının logaritması alındığında eşitlik denklem (6)'daki gibi ifade edilmektedir.

$$
\operatorname{Ln}\left(I_{t}^{k *}\right) \cong \operatorname{Ln}\left(\frac{E\left[\left(r_{t}^{k}-r^{f}\right)\right]}{\delta \operatorname{var}\left(r_{t}^{k}\right)}\right)
$$

Logaritmik ifadede bölüm ve çarpım özelliği kullanılarak yeni eşitlik denklem (7)'deki gibi yazılabilmektedir. ${ }^{2}$

$$
\operatorname{Ln}\left(I_{t}^{k *}\right) \cong \operatorname{Ln}\left(E\left[\left(r_{t}^{k}-r^{f}\right)\right]\right)-\operatorname{Ln}\left(\operatorname{var}\left(r_{t}^{k}\right)\right)-\operatorname{Ln}(\delta)
$$

Denklem (7)'de risk varyansı $\left(\operatorname{var}\left(r_{t}^{k}\right)\right)$ sabit varlık yatırımlarının politik, ekonomik ve finansal belirleyenlerine göre ayrıştırılabilir. Ekonomik $\left(\sigma_{e}^{2}\right)$, politik $\left(\sigma_{p}^{2}\right)$ ve finansal $\left(\sigma_{f}^{2}\right)$ risk olmak üzere üç farklı risk türü belirlenmiştir (Le, 2004). Her bir risk türünün birbirinden bağımsız olduğu varsayımı yapılmış ve yatırım riski denklem (8)' deki gibi ifade edilmiştir.

$$
\operatorname{VAR}\left(r_{t}^{k}\right)=\sigma_{\mathrm{e}, \mathrm{t}}^{2}+\sigma_{\mathrm{p}, \mathrm{t}}^{2}+\sigma_{\mathrm{f}, \mathrm{t}}^{2}
$$

Her bir risk türünün birbirinden bağımsız olduğu varsayımı altında sabit varlık yatırım riski denklem (8)'de yerine konulduğunda denklem (9)'daki eşitlik elde edilmektedir. ${ }^{3}$

$$
\operatorname{Ln}\left(I_{t}^{k *}\right) \cong \operatorname{Ln}\left(E\left[\left(r_{t}^{k}-r^{f}\right)\right]\right)-\operatorname{Ln}\left(\sigma_{e, t}^{2}\right)-\operatorname{Ln}\left(\sigma_{p, t}^{2}\right)-\operatorname{Ln}\left(\sigma_{f, t}^{2}\right)-\operatorname{Ln}(\delta)
$$

Temsili bir yatırımcının sahip olduğu toplam sermaye $\left(K_{t}^{a}\right)$ hem sabit sermaye $\left(I_{t}^{k *}\right)$ hem de finansal sermaye $\left(I_{t}^{f *}\right)$ 'den oluştuğu için toplam sermaye denklem (10)'daki gibi gösterilmektedir.

$$
K_{t}^{a}=I_{t}^{k *}+I_{t}^{f *}
$$

Denklem (10)'dan hareketle eşitlikte sabit varlık yatırımları $\left(I_{t}^{k *}\right)$ yerine $\left(E\left[\left(r_{t}^{k}-r^{f}\right)\right] / \delta \operatorname{var}\left(r_{t}^{k}\right)\right)$ ifadesi yazılmış ve eşitliğin her iki tarafı toplam sermayeye bölünmüş denklem (11)'de gösterilmiştir.

$\frac{I_{t}^{f *}}{K_{t}^{a}}=1-\frac{\left(\frac{E\left[\left(r_{t}^{k}-r f\right)\right]}{\delta v a r\left(r_{t}^{k}\right)}\right)}{K_{t}^{a}}$

Denklem (11)'deki eşitlik finansal yatırımlarının sabit ve finansal varlık yatırım getiri oranları açı̆̆ı $\left(r_{t}^{k}-r^{f}\right)^{\prime}$ nın azalan fonksiyonu, riskten kaçınma değerinin sabit olduğu varsayımı altında belirsizliğin artan fonksiyonu olduğunu göstermektedir.

Denklem (11)'deki eşitliğin her iki tarafının logaritması alındığında ve yatırım riski yerine konulduğunda eşitlik denklem (12)' deki gibi ifade edilmektedir.

$$
\begin{aligned}
\operatorname{Ln}\left(\frac{I_{t}^{f *}}{K_{t}^{a}}\right) & \cong-\operatorname{Ln}\left(E\left[\left(r_{t}^{k}-r^{f}\right)\right]\right)+\operatorname{Ln}\left(\sigma_{e, t}^{2}\right)+\operatorname{Ln}\left(\sigma_{p, t}^{2}\right)+\operatorname{Ln}\left(\sigma_{f, t}^{2}\right)+\operatorname{Ln}(\delta) \\
& +\operatorname{Ln}\left(K_{t}^{a}\right)
\end{aligned}
$$




\section{EKONOMETRÍK METODOLOJİ VE MODEL}

\subsection{Dinamik Panel Veri Analizi}

Çalışmada belirsizlik ve risk koşullarında Türkiye'de reel sektörde faaliyet gösteren firmaların sabit sermaye ve finansal yatırım kararlarını etkileyen faktörler, dinamik panel tahmin yöntemlerinden biri olan Genelleştirilmiş Momentler Metodunun (Generalized Methods of Moments-GMM) Arellano ve Bond (1991) tarafindan geliştirilen fark GMM versiyonu ile tahmin edilmiştir. Dinamik panel modelinin en önemli avantajlarından biri dinamik ilişkilerin araştırmacılar tarafindan daha iyi bir şekilde anlaşılmasını sağlamasıdır. Dinamik ilişkiler modele bağımlı değişkenin gecikmeli değerinin eklenmesiyle denklem (13)'teki gibi ifade edilmektedir (Duch, 2008).

$Y_{i t}=\vartheta Y_{i t-1}+\phi Z_{i}+\beta X_{i t}+\theta_{i t}+\varepsilon_{j t} j=1,2, \ldots, N$ ve $t=1,2, \ldots, T$

$Y_{i t}$, $i$ 'nci firma için $t$ zamanında gözlemlenen bağımlı değişkenin değerini; $Y_{i t-1}, i$ 'nci firma için $t-1$ zamanında gözlemlenen bağımlı değişkenin değerini; $X_{i t}, k 1 x 1$ boyutundaki vektör, $i$ 'nci firma için $t$ zamanında gözlemlenen zaman sürecinde değişen $k 1$ tane dişsal değişkenlerin değerlerini; $Z_{i}, k 2 x 1$ boyutundaki vektör, $i$ 'nci firma için zaman sürecinde değişmeyen $k 2$ tane dişsal değişkenlerin değerlerini; $\theta_{i}, i$ 'nci firma için gözlemlenemeyen firma etkisinin değerini; $\varepsilon_{j t}$, $i$ 'nci firma için $t$ zamanında gözlenemeyen hata değerini göstermektedir.

Bağımlı değişkenin gecikmeli değeri $\left(Y_{i t-1}\right)$ ile birim etkiler $\left(\theta_{i}\right)$ arasında korelasyonun bulunması, en küçük kareler yöntemi tahmincilerinin sapmalı ve tutarsız olmasına neden olmaktadır (Baltagi, 2005: 135). Bu durum hata terimlerinin $\left(\varepsilon_{j t}\right)$ bağımlı değişkeni etkilediği gibi bağımlı değişkenin gecikmeli değerini de etkilemektedir.

Bu nedenle Arellano ve Bond (1991) modelde yer alan gecikmeli değişkenlerin hepsinin dinamik panel modellerinde araç değişken olarak kullanılmasını önermektedir. Böylece hem ortoganalite kısıtlamalarını uygulayabilmek için araç değişkenlerinin hepsinin kullanılmasına izin verilmekte hem de varyans - kovaryans matrisinin parametrik olmayan bir tahmincisi kullanılmaktadır. Bu durumu ifade eden model denklem (14)'te belirtildiği gibi olmaktadır.

$$
\begin{aligned}
Y_{i t}-Y_{i t-1} & =\vartheta\left(Y_{i t-1}-Y_{i t-2}\right)+\sum_{k} \beta_{k}\left(X_{k i t}-X_{k i t-1}\right)+\sum_{s} \beta \phi_{s}\left(W_{s i t}-W_{s i t-1}\right) \\
& +\left(\varepsilon_{i t}-\varepsilon_{i t-1}\right)
\end{aligned}
$$

$X_{k i t}$, katı egzojen ortak değişkenleri (covarites) ve $W_{\text {sit }}$ ise önceden belirlenmiş (predetermined) ve endojen ortak değişkenleri ifade etmektedir. Denklem (14)'te birinci fark denklemleri alınmakla beraber gecikmeli endojen değişken parametresi ( $\vartheta)$ tahmini için araç değişkenlerin modele eklendiği gösterilmektedir.

Dinamik panel veri yöntemi ile parametrelerin tahmin edilmesi için kullanılan GMM tekniğinin en önemli varsayımlarından biri modelde kullanılan araç değişkenlerin dışsal olması varsayımıdır. Bu varsayımın geçerliliğini sınamak amacıyla çalışmada Arellano ve Bond'un birinci fark modelinde ve sistem GMM tahmininde kullanılan araç değişkenlerin tamamının geçerliliğini sınayan Sargan'ın birinci fark testi kullanılmıştır. 
Bu testlerin yanında GMM yönteminin diğer bir varsayımı ise birinci fark denkleminden elde edilen hata terimleri arasında ikinci dereceden sira korelasyonu olmaması varsayımıdır. Bu varsayımın geçerliliğini sınamak amacıyla ise Arellano ve Bond (1991) bu varsayımın geçerliliğini sınamak amacıyla geliştirdiği ardışık bağımlılık testi kullanılmıştır.

\subsection{Belirsizliğin Ölçülmesi}

Zaman serilerinde belirsizliğe ilişkin volatilite ya da oynaklık modelleri incelendiğinde volatilitenin tahmin edilen ve edilmeyen iki bileşene ayrıldığ 1 ve tahmin edilen bileşenin belirsizliğe neden olan değişkenin koşullu varyansı üzerinde yoğunlaştığı görülmektedir (Gürsakal, 2009: 322). Belirsizliğin ölçülmesinde literatürde Otoregresif Koşullu Varyans (ARCH) ile Genelleştirilmiş Otoregresif Koşullu Varyans (GARCH) sınıfı modellerin daha çok tercih edildiği ve bu modellerde belirsizliğe neden olan değişkenin koşullu varyanslarının kullanıldığı görülmektedir (Poon ve Granger, 2003: 483).

ARCH / GARCH sinıfi modellerden biri Engle (1982) tarafindan ortaya konulan Otoregresif Koşullu Değişken Varyans (ARCH) modelidir. ARCH modelinde sabit varyans varsayımının geçerli olmadığ 1 bir durumda koşullu varyans, hata terimlerinin mutlak ya da kare değeri ile koşullu gecikmeli varyanslara bağlı olmaktadır (Gürsakal, 2009: 322). Koşullu varyansın $\operatorname{AR}(p)$ modeli ile tahmini yapılmakta ve model denklem (15)'teki gibi ifade edilmektedir (Enders, 2004: 114):

$\hat{\varepsilon}_{t}^{2}=\alpha_{0}+\alpha_{1} \hat{\varepsilon}_{t-1}^{2}+\cdots+\alpha_{p} \hat{\varepsilon}_{t-p}^{2}+v_{t}$

Denklem (15)'te $v_{t}$ beyaz gürültü sürecini temsil etmektedir. LM (Lagrange Multiple) testi ile denklem (15)'teki tahmin süreci $A R(p)$ modeli olarak ele alınmakta ve ARCH etkisi LM testi ile test edilmektedir. ARCH etkisinin varlığı ve normallik varsayımı altında $\operatorname{AR}(p)$ modeli denklem (16)'daki gibi ifade edilmektedir (Engle, 1982: 987):

$y_{t} \psi_{t-1} \sim N\left(x_{t} \beta, h_{t}\right) \quad h_{t}=\alpha_{0}+\alpha_{1} \hat{\varepsilon}_{t-1}^{2}+\cdots+\alpha_{p} \hat{\varepsilon}_{t-p}^{2} \quad \varepsilon_{t}=y_{t}-x_{t} b$

Denklem (16)'daki ilk eşitlik ortalama modeli, ikinci eşitlik ise varyans modeli olarak adlandırılmaktadır. $h_{t}$ terimi ARCH modelinde kullanılan koşullu varyansı, $p$ terimi ARCH modelinin derecesini ve $\alpha$ terimi ise parametre vektörünü göstermektedir.

ARCH Modelinin bazı kısıtları bulunmaktadır. Bu kısıtlardan ilki her bir $\alpha$ parametresi pozitif değerler almasıdır $\left(\alpha_{0}>0\right.$ ve $i=1,2, \ldots p$ olmak üzere $\left.\alpha_{i} \geq 0\right)$. Denklem (16)'daki ikinci eşitlikte hata terimlerinin gecikmeli değerlerinin kareleri negatif değerler almayacağından dolayı koşullu varyans negatif değer almamaktadır. ${ }^{4}$ Diğer bir kısıt ise sabit parametre hariç $\alpha$ parametrelerinin her birinin veya toplamlarının birden küçük olmasıdır. ${ }^{5} \mathrm{Bu}$ durum modelin kararlılığı için gerekmekte ve varyansın sonsuz değer almasını engellemektedir (Engle, 1982: 993).

Bollerslev (1986) ARCH modelinin genişletilmiş hali olan GARCH modelini geliştirmiştir. Bu modelde koşullu varyansın sadece hata teriminin gecikmeli değerlerine değil, aynı zamanda kendi gecikmeli değerlerine de bağlı olduğunu belirtmiştir. Model, kalıntı karelerinin ağırlıklandırılmış ortalaması olmakla birlikte bütünüyle sıfıra gitmeyen azalan ağırlıklara sahiptir (Engle, 2001: 159). 
GARCH etkisinin tespiti ARCH etkisinin tespiti ile aynı mantıktaki LM testiyle ancak farklı hipotezler ile test edilmektedir. $\operatorname{GARCH}(p, q)$ modeli denklem (17)'de gösterilmektedir.

$y_{t} \psi_{t-1} \sim N\left(0, h_{t}\right) h_{t}=\alpha_{0}+\sum_{i=1}^{p} \alpha_{i} \hat{\varepsilon}_{t-i}^{2}+\sum_{j=1}^{q} \beta_{j} h_{t-j} \quad \varepsilon_{t}=y_{t}-x_{t} b$

Denklem (17)'de alan $y_{t}$ serisinin $\psi_{t-1}$ bilgi kümesine bağlı olarak koşullu ortalamasının 0 ve koşullu varyansı $h_{t}$ ile normal dağılıma sahip olduğu görülmektedir. $\operatorname{GARCH}(p, q)$ modelinin geçerli bir model olduğu belirli şartların sağlanması ile mümkün olmaktadır. ${ }^{6}$

Literatür incelendiğinde makroekonomik serilere ilişkin belirsizliğin ölçülmesinde ARCH modellerine kıyasla GARCH modellerinin daha sık kullanıldığı görülmektedir. Özellikle $\operatorname{GARCH}(1,1)$ modelinin birçok finansal zaman serisi için en uygun yapıda olan model olduğu düşünülmektedir (Poon ve Granger, 2003: 484).

\subsection{Model}

Fark GMM yaklaşımı ile firmaların sabit sermaye ve finansal yatırım kararları üzerinde risk ve belirsizliklerin etkisini gösteren iki farklı model (sırasıyla model A ve B) denklem (9) ve (12)'den hareketle kurulmuştur. Modeller denklem (18) ve (19)'da gösterilmiştir.

\section{Model A}

$$
\begin{aligned}
I_{i t}^{k} & =\alpha_{1} I_{i t-1}^{k}+\alpha_{2} K O_{i t-1}+\alpha_{3} \operatorname{Rgap}_{i t-1}+\alpha_{4} \text { Risk }_{i t}+\alpha_{5} V_{i t}+d_{t} \\
& +\varepsilon_{i t}
\end{aligned}
$$

Model B

$$
\begin{aligned}
\left(\frac{I^{f}}{K^{a}}\right)_{i t} & =F K_{i t}=\alpha_{1} F K_{i t-1}+\alpha_{2} F K_{i t-2}+\alpha_{3} K_{i t}^{a}+\alpha_{4} \operatorname{Rgap}_{i t-1} \\
& +\alpha_{5} \text { Risk }_{i t}+d_{t}+\varepsilon_{i t}
\end{aligned}
$$

Denklem (18) ve (19)'da $i$ 'nci firmanın $t$ zamanında $I_{i t}^{k}$, reel net sabit sermaye yatırımlarını; $F K_{i t}$, finansal yatırımlarının toplam sermaye miktarına oranını; $K O_{i t}$, sermaye hâsıla oranını; $K_{i t}^{a}$, toplam yatırım miktarını, $\operatorname{Rgap}_{i t}$, getiri oranları farkını; Risk $_{i t}$, belirsizlik ve risk değişkenini; $V_{i t}$, kontrol değişkenini; $d_{t}$, gözlemlenemeyen zaman etkisini ve $\varepsilon_{i t}$, hata değerini temsil etmektedir.

Firmaların sabit sermaye ve finansal yatırım kararları üzerinde risk ve belirsizliklerin etkilerini gösteren sırasıyla model A ve B'de, net sabit sermaye yatırımları $\left(I_{i t}^{k}\right)$, net sabit sermaye stokunun logaritmik farkı alınarak ${ }^{7}$; net finansal varlık yatırımları $\left(F K_{i t}\right)$, net finansal varlıkların net sabit ve finansal varlıkları toplamına bölünmesiyle; sermaye hâsıla oranı $\left(K O_{i t}\right)$ dönem başındaki net sabit sermaye stokunun firmanın net satışlarına bölünmesiyle; toplam yatırım miktarı $\left(K_{i t}^{a}\right)$, reel net sabit ve finansal varlık yatırımlarının toplanmasıyla elde edilmektedir (Demir, 2005: 108; Demir, 2009a: 316-318). Diğer taraftan, piyasadaki kredi olanaklarının sabit yatırımlar üzerindeki etkisini belirleyebilmek amacıyla model A'da kredi $\left(K R_{i t}\right)$ kontrol değişkeni kullanılmakta ve özel sektöre verilen toplam kredilerin GSYİH'ya oranı şeklinde hesaplanmaktadır. 
Her iki modelde de ortak kullanılan değişkenlerden getiri oranları farkı, $\left(\operatorname{Rgap}_{i t}\right)$, sabit ve finansal varlık getiri oranları farkını temsil etmektedir $\left(r_{i t}^{k}-r_{i t}^{f}\right)$. Sabit varlık yatırım getirisi $\left(r_{i t}^{k}\right)$, firmanın dönem sonundaki faaliyet kârının net maddi duran varlıklara bölünmesiyle hesaplanırken, finansal varlık yatırım getirisi $\left(r_{i t}^{f}\right)$ ise firmanın dönem sonundaki net diğer faaliyet gelirlerinin nakit ve nakit benzeri değerler toplamına bölünmesi ile hesaplanmaktadır. ${ }^{8}$

Modellerde kullanılan belirsizlik ve risk değişkenini $\left(R i s k_{i t}\right)$ enflasyon, döviz kuru ve büyüme hızı belirsizlikleri temsil etmektedir. Enflasyon $\left(B E n f_{i t}\right)$, döviz kuru $\left(B R e r_{i t}\right)$ ve büyüme hızı $\left(B G s y i h_{i t}\right)$ belirsizlikleri sırasıyla yıllık üretici fiyat endeksi, reel döviz kuru ve büyüme hızı verilerinin logaritmik farkı alındıktan sonra ARCH / GARCH modeli kullanılarak tahmin edilmektedir. Diğer taraftan, ekonomik $\left(E R_{i t}\right)$, politik $\left(P R_{i t}\right)$, finansal $\left(F R_{i t}\right)$ ve ülke $\left(I C R G_{i t}\right)$ risk endeksleri risk değişkenini $\left(R i s k_{i t}\right)$ temsil eden ve modellerde kullanılan diğer değişkenlerdir. Risk endekslerine ilişkin verilerin olasılık değerleri gibi yorumlanabilmesi amacıyla endeks verileri logaritmik dönüştürülme işlemine tabi tutulmakta ve risk endeks değişkenleri elde edilmektedir.

\section{VERİ SETİ}

Çalışmada kullanılan mikro ölçekli veriler elde edilmeden önce ilk olarak Türkiye'de menkul kıymetler borsasına kayıtlı ve 2003:01 ile 2012:12 döneminde kesintisiz olarak en az yedi yıl faaliyet göstermiş firmalar belirlenmiş ve belirlenen firmaların bu yıllara ilişkin yıllık bilanço ve gelir tabloları, dünya borsalarına kayıtlı firmalara ilişkin finansal bilgileri kayıt altına alan Thomson One Banker isimli şirketten sağlanmıştır. İlk olarak Borsa İstanbul'da kayıtlı 424 firma belirlenmiş ve bu firmalar faaliyet kollarına göre sınıflandırılmıştır. Sonrasında finansal sektörde yer alan firmalar ile kesintisiz olarak en az yedi yıl faaliyette bulunmayan firmalar çalışmadan çıkarılmıştır. Sonuç olarak elde kalan 219 firmaya ilişkin bilanço ve gelir tablolarından sağlanan veriler 2010 yılına göre uyarlanmış ve modellerde kullanılan değişkenlere ulaşılmıştır.

Analizde kullanılan 219 firma içinde 36 firma inşaat, 19 firma gıda ve içecek, 16 firma metal ve metal ürünleri imalatı, 13 firma kimyasal madde imalatı, 11 firma otomotiv, 8 firma petrol, gaz ve kömür ürünleri imalatı, 8 kâğıt sektörlerinde faaliyet gösterirken kalan 102 firma ise diğer sektörlerde faaliyet göstermektedir. Modellerde kullanılan değişkenler ve bu değişkenlere ilişkin temel bilgiler ek 1'de gösterilmiştir.

\section{TAHMIN SONUÇLARI}

\subsection{Genel Trend}

Türkiye'de reel sektörde faaliyet gösteren firmalara ilişkin sabit ve finansal varlık yatırımları getiri oranları farkı (Rgap), finansal varlık yatırımlarının toplam yatırımlara oranı (FK) ve faaliyet karlılığı oranı değişkenlerine ilişkin ortanca değerleri yıllar itibariyle sırasıyla Şekil 1'de gösterilmiştir. 
Şekil 1. Ortanca Değer Grafikleri
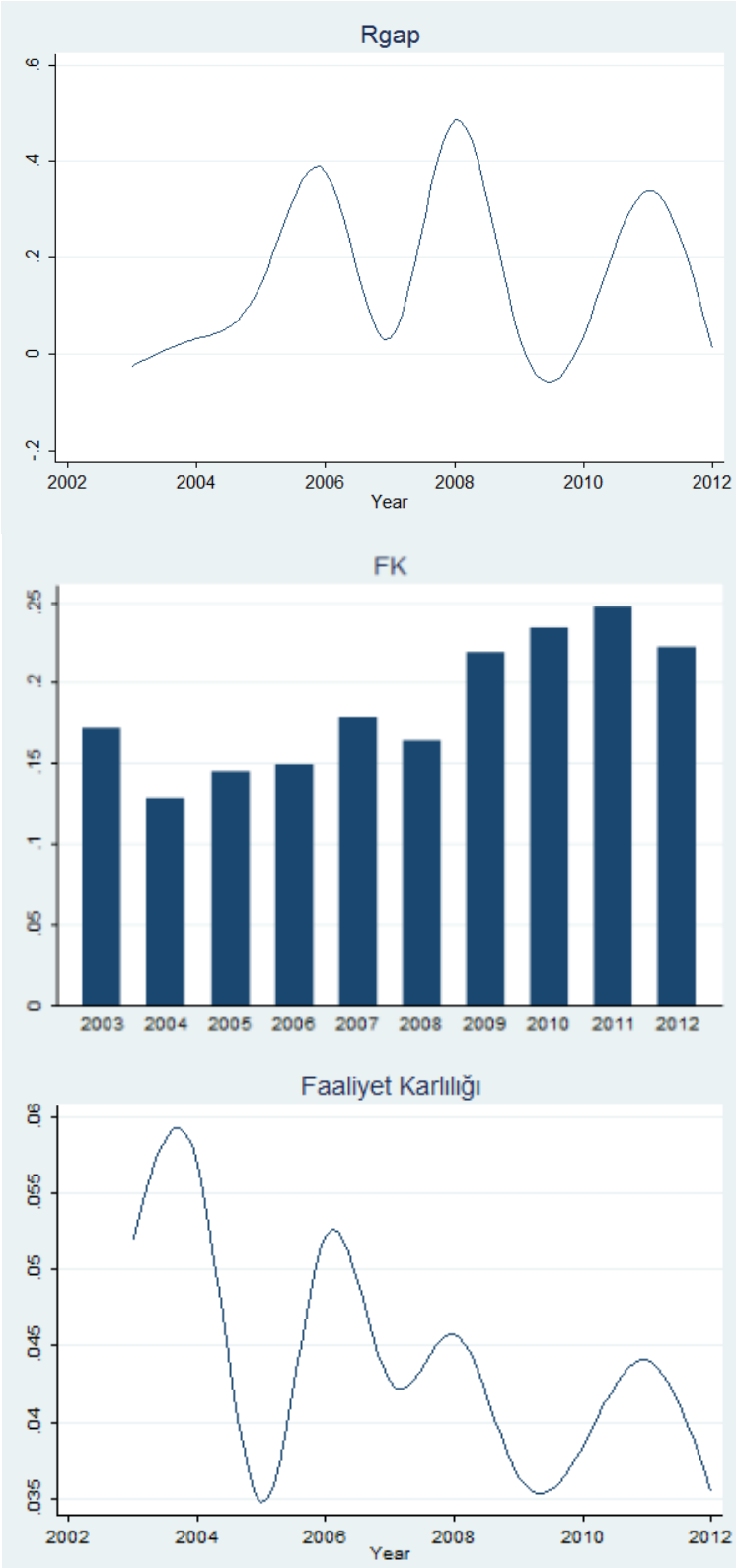

Şekil 1'de görüldüğü gibi Rgap değişkenine ilişkin ortanca değeri reel sektörde faaliyet gösteren firmalar için 2003 yılında negatif değer alırken diğer yıllarda ise pozitif değerler almıştır. Diğer taraftan bu değişken 2008 yılında en yüksek değerine ulaşmıştır. Bu durum firmaların gerçekleştirmiş oldukları sabit varlık yatırımlarından elde ettikleri getiri ile 
finansal varlık yatırımlarından elde ettikleri getiri arasındaki farkın en fazla olduğu yılın 2008 yılı olduğunu göstermektedir. Ayrıca 2009 yılına gelindiğinde Rgap değişkenine ilişkin ortanca değerin önemli bir şekilde düşüş gösterdiği görülmektedir. Bu düşüş 2007 yılının ortalarında Amerika Birleşik Devletleri ipotekli konut piyasasında başlayan, türev ürünler aracılığıyla tüm finansal sektörü etkisi altına alan ve dünya geneline yayılarak bütün ülkeleri derinden etkileyen küresel ekonomik kriz ile açıklanabilmektedir.

2003 - 2012 dönemi genel olarak ele alındığında sabit ve finansal varlık yatırımları getiri oranları farkına ilişkin ortanca değerin 0.142 olduğu görülmektedir. Bu durum reel sektörde faaliyet gösteren firmaların gerçekleştirmiş oldukları her 100 TL'lik sabit varlık yatırımından elde ettikleri getirinin, her TL'lik finansal varlık yatırımından elde ettikleri getiriden 14.2 TL daha fazla olduğunu göstermektedir. Diğer taraftan finansal varlık yatırımlarının toplam yatırımlara oranı ve faaliyet kârlılığı oranına ilişkin ortanca değerlerin sırasıyla 0.181 ve 0.042 olduğu görülmektedir. Bu durum reel sektörde faaliyet gösteren firmaların gerçekleştirdikleri her 100 TL'lik yatırımın 18.1 TL 'sının finansal varlık yatırımı olduğunu ve her 100 TL' lık satışlarında 4.2 TL faaliyet kârı elde ettiklerini göstermektedir.

\subsection{Belirsizlik Değişkenlerine İlişkin Tahmin Sonuçları}

Modellerde kullanılan belirsizlik değişkenlerini tahmin etmek amacıyla çalışmada ilk olarak enflasyon, döviz kuru ve büyüme hızı verileri, denklem (20)'deki eşitlikten hareketle 2003-2012 dönemi için aylık endeks serilerinin oluşturulmasında kullanılmıştır.

Endeks serisi $=\operatorname{Ln}\left(\frac{\text { değ isken }_{t}}{\text { değişken }_{t-1}}\right)$

Belirsizlik değişkenleri beş aşamada elde edilmiştir. İlk aşamada enflasyon, döviz kuru ve büyüme hızı endeks serilerinin normal dağılıma sahip olup olmadıkları test edilmiştir. Elde edilen bulgular serilerin normal dağıldığını göstermiş̧ir.

İkinci aşamada endeks serilerinin durağan olup olmadıkları tespit edilmiştir. Çalışmada endeks serilerinin durağanlıkları, durağanlık testlerinde yaygın olarak kullanılan Genişletilmiş Dickey-Fuller (Augmented Dickey-Fuller-ADF) (1979) birim kök testleri ile sınanmış ve endeks serilerinin düzey değerde durağan oldukları gözlenmiştir.

Üçüncü aşamada endeks serilerinde ARCH etkisinin tespit edilmesi amacıyla ARCH LM (ARCH Lagrange Multiple) testi yapılmıştır. ARCH - LM testinde ilk olarak ITSM 2000 programı ile her bir seriye ilişkin ortalama denklemin tespitinde otoregresif ve hareketli ortalama süreçleri (ARMA) kullanılarak endeks serisi on ikinci gecikmeye kadar denenmiş ve en düşük Akaike Bilgi Kriteri (AIC) katsayısına sahip model BoxJenkins metodolojisinin cimrilik özelliği de göz önünde bulundurularak ortalama denklem olarak kabul edilmiştir. Sonrasında ise ortalama denklemlerde ARCH etkisinin olup olmadığını sınamak amacıyla ARCH - LM testi uygulanmıştır. Enflasyon, döviz kuru ve büyüme hızı belirsizliklerine ilişkin test sonuçları, ortalama denklemlerde ARCH etkisinin olduğunu göstermiştir.

Dördüncü aşamada ortalama denklemlerde $\mathrm{ARCH}$ etkisinin varlı̆̆ tespit edildikten sonra uygun ARCH ve GARCH tipi modellerin seçimine geçilmiştir. Elde edilen bulgular, 
enflasyon ve döviz kuru belirsizliklerine ilişkin en uygun modelin GARCH $(1,1)$ modeli olduğunu, büyüme hızı belirsizliğine ilişkin en uygun modelin ise $\mathrm{ARCH}$ (1) modeli olduğunu göstermiştir.

Beşinci aşamada ise modellerde $\mathrm{ARCH}$ etkisinin ortadan kalktığını görmek amacıyla yeniden modellere ARCH - LM testi uygulanmıştır. Test sonuçları bütün modellerde ARCH etkisinin olmadığını göstermiştir. Sonrasında ise enflasyon, döviz kuru ve büyüme hızı endeks serilerinin aylık koşullu varyans değerleri hesaplanmıştır. Belirsizlik değişkenlerinin oluşturulması amacıyla aylık koşullu varyans değerlerinin yıllık ortalaması 2003-2012 dönemini kapsayacak şekilde hesaplanmıştır.

\subsection{Dinamik Panel Veri Analiz Sonuçları}

Çalışmada ilk olarak reel sektörde faaliyet gösteren firmaların sabit ve finansal varlık yatırımlarının belirleyicilerini tespit eden modellerde kullanılacak araç değişkenler, araç değişkenler regresyonu (Instrumental Variables Regression) yöntemi kullanılarak tespit edilmiştir. ${ }^{9}$ Sonrasında, Borsa İstanbul'da işlem gören ve reel sektörde faaliyet gösteren firmaların belirsizlik ve risk koşulları altında sabit sermaye yatırımları ile finansal yatırımlarını etkileyen faktörleri tespit eden denklem (18) ve (19)'daki iki ayrı model, Arellano ve Bond (1991)'un GMM tahmincisi kullanılarak tahmin edilmiştir.

Reel sektörde firmaların sabit sermaye yatırım kararlarını etkileyen faktörler model A'dan hareketle tahmin edilmiş ve sonuçlar Tablo 1 ve 2'de gösterilmiştir.

Tablo 1. Türkiye'de Firmaların Sabit Sermaye Yatırımlarını Belirleyen Belirsizlik Faktörlerine Yönelik Tahmin Sonuçları $\left(I^{k}\right)$

\begin{tabular}{|c|c|c|c|c|c|}
\hline & \multicolumn{5}{|c|}{ Belirsizlik Modeli } \\
\hline & (1) & (2) & (3) & (4) & (5) \\
\hline$I_{-1}^{k}$ & $\begin{array}{c}-0.2467 * * \\
(0.1154)\end{array}$ & $\begin{array}{c}-0.3384 * * * \\
(0.1966)\end{array}$ & $\begin{array}{c}-0.2190 * * \\
(0.1075)\end{array}$ & $\begin{array}{c}-0.1649 * \\
(0.0158)\end{array}$ & $\begin{array}{c}-0.1649 * \\
(0.0158)\end{array}$ \\
\hline$K O_{-1}$ & $\begin{array}{c}-0.1216^{* * *} \\
(0.0596)\end{array}$ & $\begin{array}{c}-0.2438 * \\
(0.0627)\end{array}$ & $\begin{array}{c}-0.1469 * * \\
(0.0606)\end{array}$ & $\begin{array}{c}-0.3877^{*} \\
(0.0230)\end{array}$ & $\begin{array}{c}-0.3877^{*} \\
(0.0230)\end{array}$ \\
\hline Rgap-1 $_{-1}$ & $\begin{array}{l}0.0185^{*} \\
(0.0069)\end{array}$ & $\begin{array}{c}0.0018 * * * \\
(0.0010)\end{array}$ & $\begin{array}{l}0.0172 * \\
(0.0065)\end{array}$ & $\begin{array}{l}0.0086^{*} \\
(0.0001)\end{array}$ & $\begin{array}{l}0.0086^{*} \\
(0.0001)\end{array}$ \\
\hline BEnf & $\begin{array}{c}-79.8589 * \\
(21.9237)\end{array}$ & & & & \\
\hline BRer & & $\begin{array}{l}-751.2135^{*} \\
(224.3309)\end{array}$ & & & \\
\hline BGsyih & & & $\begin{array}{c}-38.1988^{*} \\
(9.9404)\end{array}$ & & \\
\hline$K r$ & & & & $\begin{array}{c}0.1693 * * \\
(0.0717)\end{array}$ & \\
\hline Gsyih & & & & & $\begin{array}{c}0.0095^{* * *} \\
(0041) \\
\end{array}$ \\
\hline Gözlem Sayısı & 1150 & 1150 & 1150 & 1150 & 1150 \\
\hline Grup Sayıs & 212 & 212 & 212 & 212 & 212 \\
\hline$F \dot{\text { Istatistiğ} i}$ & 20.17 & 33.08 & 21.17 & 1906.23 & 1904.74 \\
\hline p-değeri & 0.000 & 0.000 & 0.000 & 0.000 & 0.000 \\
\hline
\end{tabular}




\begin{tabular}{|c|c|c|c|c|c|}
\hline$m_{1}$ & -2.72 & -1.98 & -2.78 & -2.20 & -2.19 \\
\hline$m_{1} p$-dě̆eri & 0.008 & 0.048 & 0.007 & 0.028 & 0.028 \\
\hline$m_{2}$ & -1.50 & -1.55 & -1.54 & -0.01 & -0.59 \\
\hline$m_{2} p$-değgeri & 0.133 & 0.121 & 0.125 & 0.999 & 0.553 \\
\hline Sargan & 0.08 & 6.01 & 0.09 & 3.22 & 7.74 \\
\hline Sargan p-dĕgeri & 1.000 & 1.000 & 1.000 & 1.000 & 1.000 \\
\hline
\end{tabular}

Notlar: Parantez içerisindeki değerler standart hataları göstermektedir. (-1) değeri değișkenlerin bir gecikmeli değerini göstermektedir. *, **, ***; sırasıyla \%1, \%5 ve $\% 10$ düzeyindeki anlamlılıkları ifade etmektedir. Yıllara ilişkin sabit etkiler tabloda gösterilmemiştir.

Tablo 1'de görüldüğü gibi bütün modellerde Rgap değişkeni ile firmaların sabit sermaye yatırımları arasında istatistiksel olarak anlamlı ve pozitif yönlü bir ilişki tespit edilmiştir. Bu anlamlı ilişki model 1, 3, 4 ve 5'te \% 1 anlamlılık düzeyinde, model 2'de ise \% 10 anlamlılık düzeyindedir. Rgap değişkeninin \% 1 artması firmaların sabit sermaye yatırımlarında \% 0.001 ile \% 0.019 arasında bir oranda artışa neden olmaktadır. Diğer taraftan, bütün modellerde sermaye hâsıla oranı $(K O)$ ile firmaların sabit sermaye yatırımları arasında \% 5 anlamlılık düzeyinde istatistiksel olarak negatif yönlü bir ilişki tespit edilmiştir. Bu oranda meydana gelen \% 1'lik bir artış firmaların sabit sermaye yatırımlarında \% 0.12 ile \% 0.39 arasında bir oranda azalışa yol açmaktadır.

Model 1, 2 ve 3'te enflasyon (BEnf), döviz kuru (BRer) ve büyüme hızı (BGsyih) belirsizlikleri ile firmaların sabit sermaye yatırımları arasında \% 1 anlamlılık düzeyinde istatistiksel olarak negatif yönlü bir ilişki tespit edilmiştir. Model 4 ve 5'te firmaların sabit sermaye yatırımları ile özel sektöre verilen toplam kredilerin GSYİH'ya oranı $(K r)$ ve büyüme hızı (Gsyih) arasında \% 5 anlamlılık düzeyinde istatistiksel olarak pozitif yönlü bir ilişki edilmiştir. Bu durum özel sektöre verilen toplam kredilerin GSYİH içindeki payının ve büyüme hızının \% 1 artmasının firmaların sabit sermaye yatırımlarını sırasıyla yaklaşık \% 0.16 ve \% 0.01 oranında arttırdığını göstermektedir.

Modellerin tamamı dikkate alındığında, firmaların sabit sermaye yatırım kararlarını en fazla etkileyen ekonomik faktörlerin sırasıyla döviz kuru belirsizliği, enflasyon belirsizliği, büyüme hızı belirsizliği ve kredi değişkeni; en az etkileyen faktörün ise büyüme hızı değişkeni olduğu görülmektedir.

Tablo 2'de görüldüğü gibi bütün modellerde Rgap değişkeni ile firmaların sabit sermaye yatırımları arasında istatistiksel olarak anlamlı ve pozitif yönlü bir ilişki tespit edilmiştir. Bu anlamlı ilişki model 1'de \% 1 anlamlılık düzeyinde, model 2,3 ve 4 'te ise $\% 5$ anlamlılık düzeyindedir. Rgap değişkeninin \% 1 artması firmaların sabit sermaye yatırımlarında \% 0.0008 ile \% 0.0012 arasında bir oranda artışa neden olmaktadır. Diğer taraftan, bütün modellerde sermaye hâsıla oranı ile firmaların sabit sermaye yatırımları arasında \% 1 anlamlılık düzeyinde istatistiksel olarak negatif yönlü bir ilişki tespit edilmiştir. $\mathrm{Bu}$ oranda meydana gelen \% 1'lik bir artış firmaların sabit sermaye yatırımlarında \% 0.33 ile \% 0.46 arasında bir oranda azalışa yol açmaktadır. 
Tablo 2. Türkiye'de Firmaların Sabit Sermaye Yatırımlarını Belirleyen Risk Faktörlerine Yönelik Tahmin Sonuçları $\left(I^{k}\right)$

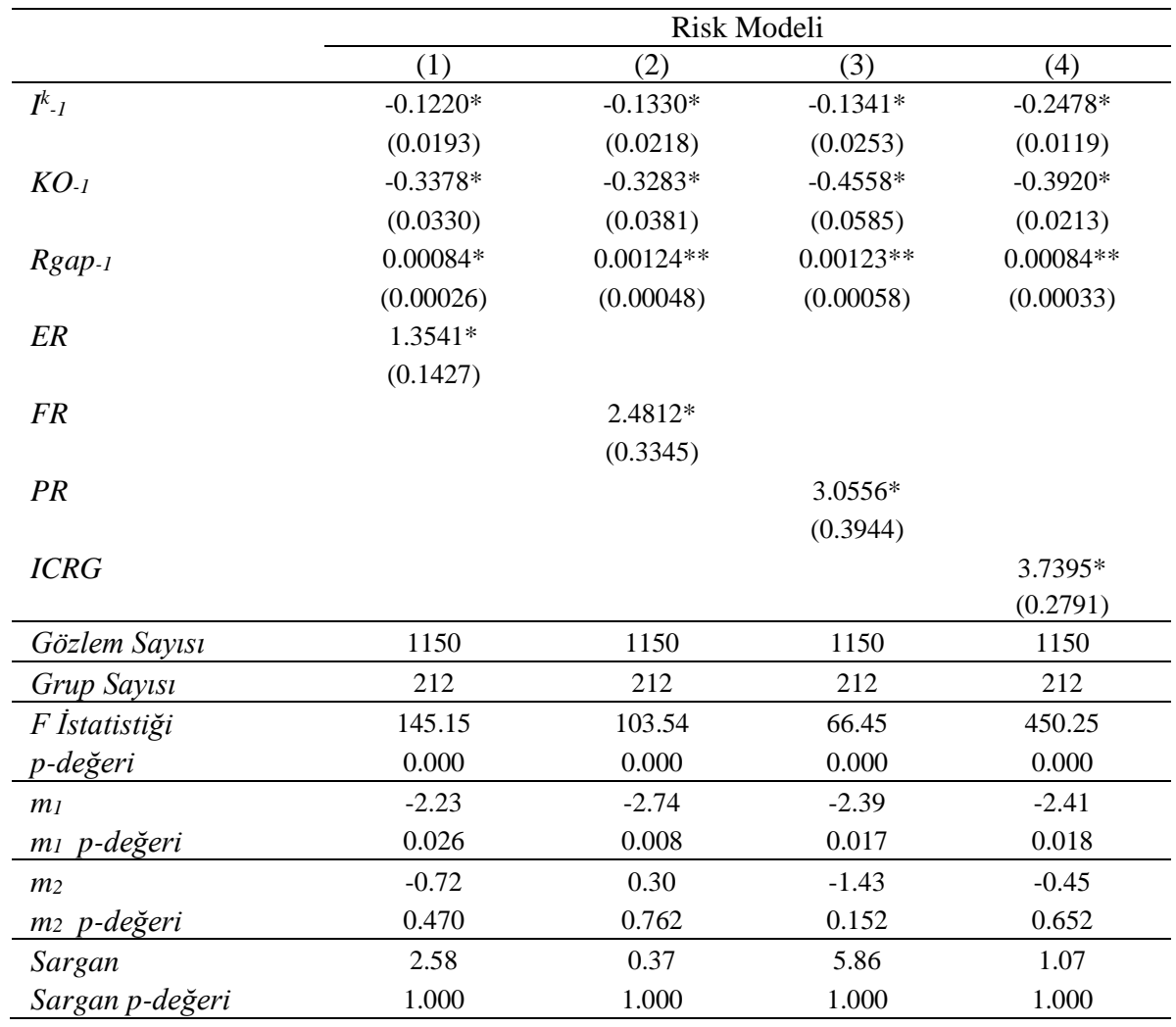

Tahmin sonuçları risk açısından ele alındığında ekonomik risk $(E R)$, finansal risk $(F R)$, politik risk $(P R)$ ve ülke riski $(I C R G)$ endeksleri ile firmaların sabit sermaye yatırımları arasında $\% 1$ anlamlılık düzeylerinde istatistiksel olarak pozitif yönlü bir ilişki tespit edilmiştir. Ekonomik, finansal, politik ve ülke risklerinde meydana gelen \% 1'lik bir artış, risk endekslerinin azalmasına neden olarak firmaların sabit sermaye yatırımlarını sırasıyla yaklaşık \% 1.35, \% 2.48, \% 3.05 ve \% 3.73 oranında azaltmaktadır.

Modellerin tamamı dikkate alındığında, firmaların sabit sermaye yatırım kararlarını en fazla etkileyen risk faktörlerinin sırasıyla ülke riski, politik risk ve finansal risk olduğu; en az etkileyen risk faktörünün ise ekonomik risk olduğu görülmektedir.

Reel sektörde firmaların finansal yatırım kararlarını etkileyen faktörler model B'den hareketle tahmin edilmiş ve sonuçlar Tablo 3 ve 4 'te gösterilmiştir. 
Tablo 3. Türkiye'de Firmaların Finansal Yatırımlarını Belirleyen Belirsizlik Faktörlerine Yönelik Tahmin Sonuçları $(F K)$

\begin{tabular}{|c|c|c|c|c|c|}
\hline & \multicolumn{5}{|c|}{ Belirsizlik Modeli } \\
\hline & $(1)$ & $(2)$ & (3) & (4) & $(5)$ \\
\hline \multirow[t]{2}{*}{$F K_{-1}$} & $-0.3874 *$ & $-0.3733^{*}$ & $-0.3912^{*}$ & $-0.3912 *$ & $-0.3728 *$ \\
\hline & $(0.0135)$ & $(0.0136)$ & $(0.0140)$ & $(0.0140)$ & $(0.0136)$ \\
\hline \multirow{2}{*}{$F K_{-2}$} & $-0.1806^{*}$ & $-0.2002 *$ & $-0.1781^{*}$ & $-0.1781^{*}$ & $-0.2009 *$ \\
\hline & $(0.0090)$ & $(0.0089)$ & $(0.0092)$ & $(0.0092)$ & $(0.0089)$ \\
\hline \multirow[t]{2}{*}{$K^{a}$} & $0.1080^{*}$ & $0.0996^{*}$ & $0.1204 *$ & $0.1204 *$ & $0.0989 *$ \\
\hline & $(0.0335)$ & $(0.0342)$ & $(0.0358)$ & $(0.0358)$ & $(0.0342)$ \\
\hline \multirow[t]{2}{*}{ Rgap-l $_{-1}$} & $-0.00085^{*}$ & $-0.00089^{*}$ & $-0.00086^{*}$ & $-0.00086^{*}$ & $-0.00089^{*}$ \\
\hline & $(0.0001)$ & $(0.0001)$ & $(0.0001)$ & $(0.0001)$ & $(0.0001)$ \\
\hline \multirow[t]{2}{*}{ BEnf } & $-281.8671^{*}$ & & & & \\
\hline & (91.0128) & & & & \\
\hline \multirow[t]{2}{*}{ BRer } & & $-137.3118^{* *}$ & & & \\
\hline & & $(66.2703)$ & & & \\
\hline \multirow[t]{2}{*}{ BGsyih } & & & $-219.2422^{* *}$ & & \\
\hline & & & $(106.0273)$ & & \\
\hline \multirow[t]{2}{*}{$K r$} & & & & $-1.1018 * *$ & \\
\hline & & & & $(0.5328)$ & \\
\hline \multirow{2}{*}{ Gsyih } & & & & & $0.0125^{*}$ \\
\hline & & & & & $(0031)$ \\
\hline Gözlem Sayısı & 1541 & 1541 & 1541 & 1541 & 1541 \\
\hline Grup Saylst & 216 & 216 & 216 & 216 & 216 \\
\hline$F \dot{\text { Istatistiğ } i}$ & 2239.67 & 2197.81 & 2053.41 & 2053.41 & 2197.37 \\
\hline p-dĕgeri & 0.000 & 0.000 & 0.000 & 0.000 & 0.000 \\
\hline$m_{1}$ & -6.15 & -6.06 & -5.98 & $\begin{array}{l}-5.98 \\
\end{array}$ & -6.07 \\
\hline$m_{1} p$-dĕgeri & 0.000 & 0.000 & 0.000 & 0.000 & 0.000 \\
\hline$m_{2}$ & 0.85 & 1.41 & 0.74 & 0.74 & 1.43 \\
\hline$m_{2}$ p-değeri & 0.393 & 0.159 & 0.461 & 0.461 & 0.153 \\
\hline Sargan & 93.97 & 92.59 & 94.03 & 94.03 & 92.56 \\
\hline Sargan p-değeri & 0.286 & 0.321 & 0.259 & 0.259 & 0.322 \\
\hline
\end{tabular}

Notlar: Parantez içerisindeki değerler standart hataları göstermektedir. (-1) ve (-2) değeri değişkenlerin bir ve iki gecikmeli değerini göstermektedir.

Tablo 3'te görüldüğü gibi bütün modellerde Rgap değişkeni ile firmaların finansal yatırımları arasında \% 1 anlamlılık düzeyinde istatistiksel olarak negatif yönlü bir ilişki tespit edilmiştir. Rgap değişkeninin \%1 azalması firmaların finansal yatırımlarında yaklaşık \% 0.0009 oranında artışa neden olmaktadır. Diğer taraftan, modellerin hepsinde firmaların gerçekleştirdikleri toplam yatırım miktarı $\left(K^{a}\right)$ ile finansal yatırımları arasında \% 1 anlamlılık düzeyinde istatistiksel olarak pozitif yönlü bir ilişki tespit edilmiştir. Firmaların gerçekleştirdikleri toplam yatırım miktarında meydana gelen \% 1'lik bir artış firmaların finansal yatırımlarını \% 0.09 ile \% 0.12 arasında bir oranda arttırmaktadır.

Model 1, 2 ve 3'te döviz kuru ve büyüme hızı belirsizlikleri ile firmaların finansal yatırımları arasında \% 5 anlamlılık düzeyinde, enflasyon belirsizliği ile ise \% 1 anlamlılık düzeyinde istatistiksel olarak negatif yönlü bir ilişki tespit edilmiştir. Model 4 ve 5 'te 
firmaların finansal yatırımları ile özel sektöre verilen toplam kredilerin GSYİH'ya oranı ve büyüme hızı arasında \% 1 anlamlılık düzeyinde istatistiksel olarak anlamlı bir ilişki tespit edilmiştir. Bu ilişkinin özel sektöre verilen toplam kredilerin GSYİH'ya oranı ve firmaların finansal yatırımları arasında negatif, büyüme hızı ve firmaların finansal yatırımları arasında ise pozitif yönlü olduğu görülmektedir. Bu durum sektöre verilen toplam kredilerin GSYİH içindeki payının $\% \quad 1$ artmasının firmaların finansal yatırımlarını yaklaşık \%1.1 oranında azalttığını; büyüme hızının \% 1 artmasının ise firmaların finansal yatırımlarını yaklaşı \% 0.012 oranında arttırdığını göstermektedir.

Modellerin tamamı dikkate alındığında, firmaların finansal yatırım kararlarını en fazla etkileyen ekonomik faktörlerin sırasıyla enflasyon belirsizliği, büyüme hızı belirsizliği, döviz kuru belirsizliği ve kredi değişkeni; en az etkileyen faktörün ise büyüme hızı değişkeni olduğu görülmektedir.

Tablo 4. Türkiye'de Firmaların Finansal Yatırımlarını Belirleyen Risk Faktörlerine Yönelik Tahmin Sonuçları $(F K)$

\begin{tabular}{|c|c|c|c|c|}
\hline & \multicolumn{4}{|c|}{ Risk Modeli } \\
\hline & (1) & (2) & (3) & (4) \\
\hline \multirow[t]{2}{*}{$F K_{-1}$} & $-0.3714^{*}$ & $-0.3682^{*}$ & $-0.3699 *$ & $-0.3703 *$ \\
\hline & $(0.0136)$ & $(0.0135)$ & $(0.0136)$ & $(0.0136)$ \\
\hline \multirow[t]{2}{*}{$F K_{-2}$} & $-0.2034 *$ & $-0.2097 *$ & $-0.2061^{*}$ & $-0.2054 *$ \\
\hline & $(0.0087)$ & $(0.0083)$ & $(0.0086)$ & $(0.0086)$ \\
\hline \multirow[t]{2}{*}{$K^{a}$} & $0.0996^{*}$ & $0.1063 *$ & $0.1012 *$ & $0.1007 *$ \\
\hline & $(0.0348)$ & $(0.0349)$ & $(0.0345)$ & $(0.0345)$ \\
\hline \multirow[t]{2}{*}{ Rgap-l $_{-1}$} & $-0.00089 *$ & $-0.00091 *$ & $-0.00090^{*}$ & $-0.00090 *$ \\
\hline & $(0.0001)$ & $(0.0001)$ & $(0.0001)$ & $(0.0001)$ \\
\hline \multirow[t]{2}{*}{$E R$} & $0.4991 *$ & & & \\
\hline & $(0.1332)$ & & & \\
\hline \multirow[t]{2}{*}{$F R$} & & $1.4048 * *$ & & \\
\hline & & $(0.5497)$ & & \\
\hline \multirow[t]{2}{*}{$P R$} & & & $2.4920^{*}$ & \\
\hline & & & $(0.7418)$ & \\
\hline \multirow[t]{2}{*}{$I C R G$} & & & & $1.2125^{*}$ \\
\hline & & & & $(0.3496)$ \\
\hline Gözlem Sayısı & 1541 & 1541 & 1541 & 1541 \\
\hline Grup Sayıst & 216 & 216 & 216 & 216 \\
\hline$F \dot{\text { Istatistiğ } i}$ & 2199.81 & 2220.69 & 2205.10 & 2203.44 \\
\hline p-değgeri & 0.000 & 0.000 & 0.000 & 0.000 \\
\hline$m_{1}$ & -6.05 & -6.01 & -6.04 & -6.04 \\
\hline$m_{1} p$-de ̌̆geri & 0.000 & 0.000 & 0.000 & 0.000 \\
\hline$m_{2}$ & 1.49 & 1.63 & 1.55 & 1.54 \\
\hline$m_{2} p$-dĕ̌geri & 0.136 & 0.102 & 0.120 & 0.124 \\
\hline Sargan & 92.44 & 92.20 & 92.31 & 92.34 \\
\hline Sargan p-değeri & 0.325 & 0.331 & 0.328 & 0.327 \\
\hline
\end{tabular}

Tablo 4’te görüldüğü gibi bütün modellerde Rgap değişkeni ile firmaların finansal yatırımları arasında $\% 1$ anlamlılık düzeyinde istatistiksel olarak negatif yönlü bir ilişki tespit edilmiştir. Rgap değişkeninin \%1 azalması firmaların finansal yatırımlarında yaklaşık \%0.0009 oranında artışa neden olmaktadır. Diğer taraftan, modellerin hepsinde firmaların gerçekleştirdikleri toplam yatırım miktarı ile finansal yatırımları arasında $\% 1$ 
anlamlılık düzeyinde istatistiksel olarak pozitif yönlü bir ilişki tespit edilmiştir. Firmaların gerçekleştirdikleri toplam yatırım miktarında meydana gelen \%1'lik bir artış firmaların finansal yatırımlarını \%0.09 ile \%0.10 arasında bir oranda arttırmaktadır.

Tahmin sonuçları risk açısından ele alındığında ekonomik risk, politik risk ve ülke riski endeksleri ile firmaların finansal yatırımları arasında $\% 1$ anlamlılık düzeyinde; finansal risk endeksi ile ise $\% 5$ anlamlılık düzeyinde istatistiksel olarak anlamlı ve pozitif yönlü bir ilişki tespit edilmiştir. Ekonomik, finansal, politik ve ülke risklerinde meydana gelen $\% 1$ 'lik bir artış, risk endekslerinin azalmasına neden olarak firmaların finansal yatırımlarını sırasıyla yaklaşık $\% 0.49, \% 1.4, \% 2.5$ ve $\% 1.21$ oranında azaltmaktadır.

Modellerin tamamı dikkate alındığında, firmaların finansal yatırım kararlarını en fazla etkileyen risk faktörlerinin sırasıyla politik risk, finansal risk ve ülke riski olduğu; en az etkileyen risk faktörünün ise ekonomik risk olduğu görülmektedir.

Tablo 1, 2, 3 ve 4'te görüldüğü gibi bütün modellerde $m_{l}$ olasıllk değerleri (p-değeri) 0.05 'ten küçük değerler alırken $m_{2}$ olasılık değerlerinin (p-değeri) 0.05 'ten büyük değerler aldığı görülmektedir. $m_{l}$ olasılık değerlerinin (p-değeri) 0.05 'ten küçük değerler alması \% 5 anlamlılık düzeyinde bu modellere ilişkin hata terimlerinde birinci dereceden otokorelasyon olduğunu göstermektedir. Diğer taraftan modellerin hepsinde $m_{2}$ olasıllk değerlerinin (p-değeri) 0.05 ’ten büyük değerler alması ise $\% 5$ anlamlılık düzeyinde modellere ilişkin hata terimlerinde ikinci dereceden otokorelasyon olmadığını göstermektedir. Ayrıca, modellerin hepsinde sargan olasılık değerleri (p-değeri) 0.05 'ten büyük değerler aldığı görülmektedir. Bu durum istatistiksel olarak $\% 5$ anlamlılık düzeyinde modellerde kullanılan araç değişkenlerin geçerli olduğu sonucunu ortaya çıkarmaktadır.

\section{SONUÇ VE DEĞERLENDİRME}

Bu çalışmada 2003-2012 dönemi itibariyle, belirsizlik ve risk faktörlerinin Türkiye'de reel sektörde faaliyet gösteren firmaların sabit sermaye ve finansal yatırım kararları üzerindeki etkileri araştırılması amaçlanmıştır. Bu doğrultuda, enflasyon, döviz kuru ve büyüme hızı belirsizlikleri ile ekonomik, finansal, politik ve ülke risklerinin firmaların sabit sermaye ve finansal yatırım kararları üzerindeki etkileri, dinamik panel veri analiz yöntemlerinden Arellano ve Bond tarafindan 1991 yılında geliştirilen GMM tahmin tekniği kullanılarak analiz edilmişsir. Analiz sonuçları özetle şöyledir:

Enflasyon, döviz kuru ve büyüme hızı belirsizliklerinin firmaların sabit sermaye ve finansal yatırımları üzerindeki etkisine bakıldığında, döviz kuru belirsizliğinin firmaların sabit sermaye yatırım kararları üzerinde, enflasyon ve büyüme hızı belirsizliklerinin finansal yatırım kararları üzerinde daha güçlü bir etkiye sahip olduğu görülmektedir. Döviz kuru belirsizliğinin azaldığı bir ortamda firmalar sabit sermaye yatırımlarını finansal yatırımlarına göre nispi olarak daha fazla; enflasyon ve büyüme hızı belirsizliklerinden herhangi birinin azaldığı ortamda ise finansal yatırımlarını sabit sermaye yatırımlarına göre nispi olarak daha fazla arttırmaktadırlar. Bu durum makroekonomik belirsizliğin genel olarak etkisinin finansal piyasalar üzerinde etkili olduğunu ve finansal piyasaların kırılgan bir yapıya sahip olduğunu gösterebilmektedir. 
Özel sektöre verilen kredilerin GSYİH içindeki payı değişkeninin firmaların sabit sermaye ve finansal yatırımları üzerindeki etkisi farklı büyüklükte ve zıt yönde olduğu görülmektedir. Kredilerin GSYIH içindeki payında meydana gelen artışın firmaların finansal yatırım kararları üzerinde sabit sermaye yatırım kararlarına göre daha güçlü bir etki yarattı̆̆ını göstermektedir. Artan kredi miktarının büyük bir bölümünün firmalar tarafından sabit sermaye yatırımlarda kullanıldığını gösterebileceği gibi finansal piyasalardan reel piyasalara doğru kaynak aktarımının olduğunun göstergesi olabilmektedir.

Büyüme hızının firmaların sabit sermaye ve finansal yatırımları üzerinde farklı büyüklükte ve aynı yönde etkisi olduğu görülmektedir. Büyüme hızında meydana gelen bir artış, firmaların finansal yatırım kararları üzerinde sabit sermaye yatırım kararlarına göre daha güçlü bir etkiye sahip olduğu görülmektedir. Artan gelirin büyük bir bölümünün firmalar tarafından kısa vadeli likit finansal yatırımlarda ve daha küçük bir bölümünün ise sabit sermaye yatırımlarında kullanıldığını gösterebilmektedir.

Ekonomik, finansal, politik risk ve ülke riskinin firmaların sabit sermaye yatırım kararları üzerinde finansal yatırım kararlarına göre daha güçlü bir etkiye sahip olduğu görülmektedir. Bu tür risklerin azalması, risk endekslerinin artmasına neden olarak firmaların sabit sermaye yatııımlarını finansal yatıımlarına göre sırasıyla yaklaşık 3, 0.8, 0.3 ve 3 kat daha fazla artırmaktadır. Bu durum risk karşısında reel piyasaların finansal piyasalara göre daha kırılgan bir yapıya sahip olduğunun bir kanıtı olabilmektedir.

Ekonomik faktörlerin firmaların finansal yatırımlarını sabit sermaye yatırımlarına göre daha olumsuz etkilemesi iki şekilde açıklanabilmektedir. İlk olarak bu faktörlerde meydana gelen artış, ülkeye olan güvenin azalmasına sebep olmaktadır. Güvenin azalması ile birlikte ülkeye giren yabancı sermaye miktarında bir azalış olabileceği gibi ülkede bulunan yabancı sermayenin de ülkeden çımasına yol açabilmektedir. Yabancı portföy yatırımlarının doğrudan yabancı sermaye yatırımlarından daha fazla azalması durumunda, finansal yatırımlar sabit sermaye yatırımlarına göre daha fazla etkilenebilmektedir. İkinci olarak bu durum sabit sermaye yatırımları ve finansal yatırımlar arasındaki yapısal farklılıklardan kaynaklanabilmektedir. Sabit sermaye yatırımları uzun vadeli ve geri çevrilemez iken finansal yatırımlar daha kısa vadeli ve batık maliyeti içermeyen yatırımlardır. Sabit sermaye yatırımlarında uyarlama maliyeti ve tamamlanma gecikmesi söz konusu iken finansal yatırımlar için böyle bir durumun söz konusu olmamasidir.

Diğer taraftan, firmaların sabit sermaye ve finansal yatırım kararlarını belirleyen risk faktörleri dikkate alındığında risk faktörlerinin, firmaların sabit sermaye yatırım kararları üzerinde finansal yatırım kararlarına göre daha etkili olduğu görülmektedir. Riskin arttığı bir durumda sabit sermaye yatırımlarının finansal yatırımlara göre daha olumsuz etkilenmesi uluslararası sermaye hareketleri ile açıklanabilmektedir. Artan risk, ülkeye olan güvenin azalmasına neden olmakta ve ülkeye giren yabancı sermaye miktarını olumsuz yönde etkileyebilmektedir. Bu durum hem sermaye hem de borçlanma maliyeti üzerinde bir artışa sebep olarak firmaların sabit sermaye yatırımlarının azalmasına yol açabilmektedir. Ayrıca, doğrudan yabancı sermaye yatırımlarının azalması sabit sermaye yatırımlarının finansal yatırımlara oranla daha fazla etkilenmesine neden olabilmektedir. Bununla birlikte risk ile getiri arasındaki doğrusal ilişki nedeniyle, riskin artması risk 
primini artırmaktadır. Riski seven yabancı yatırımcıların daha yüksek getiri elde edebilmek amacıyla Türkiye'de yatırım yapması, riskin finansal yatırımlar üzerindeki olumsuz etkisini azaltmakta ve finansal yatırımların sabit sermaye yatırımlarına göre daha az etkilenmesine neden olabilmektedir.

Sonuç olarak belirsizlik ve risk faktörlerinin firmaların sabit sermaye ve finansal yatırım kararlarına etkisi beraber analiz edildiğinde, ekonomik ve politik faktörlerin firmaların finansal yatırım kararlarına olan etkisinin, risk faktörlerinin ise sabit sermaye yatırım kararlarına olan etkisinin daha fazla olduğu görülmektedir. Ayrıca firmaların sabit sermaye ve finansal yatırım kararlarında belirsizlik durumunda sergiledikleri tutumu risk karşısında sergilemedikleri görülmektedir.

\section{NOTLAR}

${ }^{1}$ Stein Lemma: $x$ ile $y$ değişkenleri tesadüfi değişkenler olduğu ve $g(x)$ ve $y$ 'nin normal dağılıma sahip oldukları varsayımı altında, $\operatorname{cov}(g(x), y)=E\left[g(x)^{\prime}\right] \operatorname{cov}(x, y)$ dir Eğer $g(x)$ ve $y$ normal dağılıma sahip değilse merkezi limit teoremi ile $\operatorname{cov}(g(x), y) \cong$ $E\left[g(x)^{\prime}\right] \operatorname{cov}(x, y)^{\prime}$ dir (Huang ve Litzenberger,1988)

${ }^{2}$ Logaritmik ifadede bölüm ve çarpım özelliği $\log \left(\frac{a}{b}\right)=\log (a)-\log (b) \quad$ ve $\log (a b)=\log (a)+\log (b)$ şeklinde ifade edilmektedir.

${ }^{3}$ Risk varyanslarının sıfıra yakın çok küçük değerler alması sonucu $\operatorname{Ln}\left(\sigma_{e, t}^{2}+\sigma_{p, t}^{2}+\right.$ $\left.\sigma_{f, t}^{2}\right)$ ile $\operatorname{Ln}\left(\sigma_{e, t}^{2}\right)+\operatorname{Ln}\left(\sigma_{p, t}^{2}\right)+\operatorname{Ln}\left(\sigma_{f, t}^{2}\right)$ ifadesinin yaklaşı olarak birbirine eşit olduğu varsayılmıştır.

${ }^{4}\left(\hat{\varepsilon}_{t-1}^{2}, \hat{\varepsilon}_{t-2}^{2}, \ldots, \hat{\varepsilon}_{t-p}^{2} \geq 0\right.$ ve $\left.h_{t}>0\right)$

${ }^{5}\left(\alpha_{1}+\alpha_{2}+\cdots+\alpha_{p}<1\right.$ ve $i=1,2, \ldots, p$ olmak üzere $\left.\alpha_{i}<1\right)$

${ }^{6} p>0$ ve $q \geq 0, \quad \mathrm{i}=1,2, \ldots, \mathrm{p} \quad \mathrm{j}=1,2, \ldots, \mathrm{q}$ değerleri için $\alpha_{0}>0, \alpha_{i} \geq 0$ ve $\beta_{j} \geq 0$ 'dır.

7 Net sabit varlık yatırımları $=\log \left(K_{i t} / K_{i, t-1}\right)=\log \left(1+\Delta K_{i t} / K_{i, t-1}\right) \cong$ $\Delta K_{i t} /_{K_{i, t-1}} \cong I_{i t} /_{K_{i, t-1}}-\delta, \delta$ Yıpranma payını ve $K_{i t}$ firmanın sahip olduğu net sabit (duran) varlıkları göstermektedir (Mairesses, Hall ve Mulkay,1998:9)

${ }^{8}$ Faaliyet Karı = Net Satışlar-Satılan Malın Maliyeti- Faaliyet Giderler ve Net Maddi Duran Varlıklar $=($ Dönem başı Maddi Duran Varlıklar + Dönem sonu Maddi Duran Varlıklar ) / 2 şeklinde hesaplanmıştır.

${ }^{9}$ Araç değişken regresyon yöntemlerinden GMM metodu kullanılarak elde edilen araç değişkenlerinin geçerliliğini gösteren matrisler, araç değişken regresyon yöntemi kullanılarak elde edilen modellere ait hata payları ile araç değişkenleri arasında bir ilişki olmadığını göstermektedir. $\mathrm{Bu}$ durum araç değişkenlerinin geçerli olduğunu göstermektedir. 


\section{KAYNAKÇA}

Aizenman, J., \& Marion, N. P. (1993). Macroeconomic Uncertainty and Private Investment. Economics Letters, 41(2), 207-210. doi:10.1016/0165-1765(93)90198-L

Alesina, A., \& Perotti, R. (1996). Income Distribution, Political Instability, and Investment. European Economic Review, 40(6), 1203-1228. doi:10.1016/00142921(95)00030-5

Arellano, M., \& Bond, S. (1991). Some Tests of Specification for Panel Data: Monte Carlo Evidence and an Application to Employment Equations. The Review of Economic Studies, 58(2), 277-297. doi: 10.2307/2297968

Arestis, P., González, A. R., \& Dejuán, Ó. (2012). Investment, Financial Markets, and Uncertainty. Levy Economics Institute Economics Working Paper Archive. WP. No. 743.

Arslan, Y., Demirhan, A. A., Hulagu, T., \& Sahinoz, S. (2012). Belirsizlik Altında Yatırım Planlarl. CBT Research Notes in Economics, No. 2012-13. Ankara: Central Bank of the Republic of Turkey.

Baltagi, B. (2005). Econometric Analysis of Panel Data. Canada: John Wiley \& Sons.

Bollerslev, T. (1986). Generalized Autoregressive Conditional Heteroskedasticity. Journal of Econometrics, 31(3), 307-327. doi:10.1016/0304-4076(86)90063-1

Campos, N. F., \& Nugent, J. B. (2003). Aggregate Investment and Political Instability: An Econometric Investigation. Economica, 70(279), 533-549. doi: 10.1111/14680335.01081

Demir, F. (2005). Financial Liberalization, Private Investment and Low Growth Traps in Argentina, Mexico and Turkey: Limits of Growth without Investment. IN: University of Notre Dame.

Demir, F. (2009a). Macroeconomic Uncertainty and Private Investment in Argentina, Mexico and Turkey. Applied Economics Letters, 16(6), 567-571. doi: $10.1080 / 13504850701206528$

Demir, F. (2009b). Financial Liberalization, Private Investment and Portfolio Choice: Financialization of Real Sectors in Emerging Markets. Journal of Development Economics, 88(2), 314-324. doi: 10.1016/j.jdeveco.2008.04.002

Duch, R. (2008). Longitudinal/Panel Data Analysis: Lecture 3 and 4. (Erişim: 27.11.2014), http://www.raymondduch.com/class/panel\%20data.

Enders, W. (2004). Applied Econometric Time Series. New York: John Willey and Sons.

Engle, R. (2001). GARCH 101: GARCH 101: The Use of ARCH/GARCH Models in Applied Econometrics. The Journal of Economic Perspectives, 15(4), 157-168.

Engle, R. F. (1982). A General Approach to Lagrange Multiplier Model Diagnostics. Journal of Econometrics, 20(1), 83-104. doi:10.1016/0304-4076(82)90104-X 
Escaleras, M., \& Kottaridi, C. (2014). The Joint Effect of Macroeconomic Uncertainty, Sociopolitical Instability, and Public Provision on Private Investment. The Journal of Developing Areas, 48(1), 227-251. doi: 10.1353/jda.2014.0019

Günçavdi, Ö., \& McKay, A. (2003). Macroeconomic Adjustment and Private Manufacturing Investment in Turkey: A Time-Series Analysis. Applied Economics, 35(18), 1901-1909. doi: 10.1080/00036840310001628099

Gürsakal, S. (2009). Varyans Kırılması Gözlemlenen Serilerde Garch Modelleri: Döviz Kuru Oynaklığı Örneği. Erciyes Üniversitesi İktisadi ve İdari Bilimler Fakültesi Dergisi, 32, 319-337.

Huang, C. F., \& Litzenberger, R. H. (1988). Foundations for Financial Economics. Netherlands: North-Holland.

Karapınar, G. (2008). Uncertainty and Investment: Evidence from the Panel Data of Turkish Manufacturing Firms. Yayınlanmamış Yüksek Lisans Tezi. İstanbul: Marmara Üniversitesi.

Koç, H., \& Değer, M. K. (2010). Döviz Kuru Belirsizliği ve Yurtiçi Yatırımlar: Türkiye Ekonomisi Üzerine Nedensellik Testleri (1988-2007). Atatürk Üniversitesi İktisadi ve Idari Bilimler Dergisi, 24(3), 79-93.

Le, Q. V. (2004). Political and Economic Determinants of Private Investment. Journal of International Development, 16(4), 589-604. doi: 10.1002/jid.1109

Le, Q. V., \& Zak, P. J. (2006). Political Risk and Capital Flight. Journal of International Money and Finance, 25(2), 308-329. doi: 10.1016/j.jimonfin.2005.11.001

LeRoy, S. F., \& Singell, L. D. (1987). Knight on Risk and Uncertainty. Journal of political economy, 95(2), 394-406.

Luintel, K. B., \& Mavrotas, G. (2005). Examining Private Investment Heterogeneity. Evidence from a Dynamic Panel. World Institute for Development Economic Research (UNU-WIDER). WP. No. 2005/11.

Mairesse, J., Hall, B. H., \& Mulkay, B. (1999). Firm-Level Investment in France and the United States: An Exploration of What We Have Learned in Twenty Years. NBER Working Paper Series. WP. No. 7437.

Özçiçek, Ö. (2007). Nominal Kur Oynaklığı ve Türkiye’de Sermaye Yatırımı Üzerindeki Etkisi. Anadolu Üniversitesi Sosyal Bilimler Dergisi, 7(2), 73-84.

Özman, M. (1996). Türkiye Ekonomisinde Belirsizliğin Özel Yatırım Harcamalarına Etkisi. Yayınlanmamış Yüksek Lisans Tezi. Ankara: Orta Doğu Teknik Üniversitesi.

Poon, S. H., \& Granger, C. W. (2003). Forecasting Volatility in Financial Markets: A Review. Journal of economic literature,41(2), 478-539. doi: $10.1257 / 002205103765762743$

Pradhan, G., Schuster, Z., \& Upadhyaya, K. P. (2004). Exchange Rate Uncertainty and the Level of Investment in Selected South-East Asian Countries. Applied Economics, 36(19), 2161-2165. doi: 10.1080/0003684042000282498 
Sile, A. E. (2003). The Effects of Macroeconomic Uncertainty on Irreversible Investment. $\mathrm{PhD}$ Thesis. Georgetown University.

Tobin, J. (1965). Money and Economic Growth. Econometrica, 33(4), 671-684. doi: $10.2307 / 1910352$

Tornell, A. (1990). Real vs. Financial Investment: Can Tobin Taxes Eliminate the Irreversibility Distortion?. Journal of Development Economics, 32(2), 419-444. doi:10.1016/0304-3878(90)90045-D

\section{EK 1:}

Firmaların bilanço ve gelir tablolarında elde edilen veriler üretici fiyat endeksi kullanılarak 2010 yılı fiyatlarına göre uyarlanmış ve analizlerde kullanılan mikro ölçekli değişkenler elde edilmiştir.

$I^{k}$ : Firmanın sahip olduğu sabit varlık yatırımı toplamını ifade etmektedir. Net sabit varlık yatırımları net sabit sermaye stokunun logaritmik farkı alınarak hesaplanmıştır.

$I^{f}$ : Firmanın sahip olduğu finansal varlık yatırımı toplamını ifade etmektedir. Toplam finansal varlık ise nakit, vadeli hesaplar, vadesiz hesaplar ve çekleri içeren dönen varlıklar ile hisse senetleri, özel sektör bonoları, devlet tahvili, hazine bonosu ve repo içeren kısa dönem finansal yatırımları toplamından oluşmaktadır.

$K$ : Firmanın sahip olduğu net sabit sermaye stoğunu göstermektedir. Net sabit sermaye stoğu, dönem sonu toplam maddi duran varlıklardan amortismanlar ve arazi ile binaların çıkarılması ile elde edilmiştir.

$K^{a}$ : Firmanın sahip olduğu sabit ve finansal varlık yatırımları toplamını ifade etmektedir. Diğer bir ifadeyle toplam yatırımlar firmanın dönem sonu sahip olduğu net sabit varlıklar ile finansal varlıklarının toplamından oluşmaktadır.

$I^{f} / K^{a}$ : Dönem sonu itibariyle firmanın sahip olduğu finansal varlık toplamının toplam yatırımlar içindeki payını göstermektedir.

$r^{f}$ : Firmanın sahip olduğu finansal varlıklardan elde ettiği getiri oranını ifade etmektedir. $\mathrm{Bu}$ oran firmanın faaliyet dışı gelirlerinin toplam finansal varlıklarına bölünmesi ile elde edilmiştir.

$r^{k}$ : Firmanın sahip olduğu sabit varlıklardan elde ettiği getiri oranını ifade etmektedir. Bu oran firmanın dönem sonu net satışlarından satılan malın maliyeti ve faaliyet giderleri düşülerek hesaplanan faaliyet gelirlerinin net sabit sermaye stoğununa bölünmesi ile elde edilmiştir.

$K O$ : Firmanın sermaye hasıla oranını ifade etmektedir. Bu oran dönem başı net sabit sermaye stoğunun net satışlara bölünerek hesaplanmıştır.

$B E n f$ : Enflasyon belirisizliğini temsil eden bu değişkenin hesaplanmasında OECD veritabanından alınan ve 2003:01-2012:12 dönemini kapsayan üretici fiyat endeksi kullanılmıştır.

BRer : Döviz kuru belirsizliğini temsil eden bu değişkenin hesaplanmasında BIS (Bank for International Settlements) veritabanından alınan ve 2003:01-2012:12 dönemini 
kapsayan 61 ülkeye göre ağırlıklandırılmış aylık reel döviz kuru verileri kullanılmıştır.

BGsyih : Büyüme hızı belirsizliğini temsil eden bu değişkenin hesaplanmasında OECD veritabanından alınan ve 1996:Q2-2012:Q4 dönemini kapsayan üç aylık büyüme hızı verileri kullanılmıştır.

$K r$ : Bankalar tarafından özel sektörde yer alan firmalara kullandırılan kredi toplamının GSYİH içindeki payı olarak tanımlanmaktadır. Bu değişkene ilişkin veri seti yıllık olarak 2003:01-2012:12 dönemini kapsayacak şekilde Word DataBank veritabanından alınmıştır.

Gsyih : Büyüme hızını temsil eden bu değişkene ilişkin veri seti yıllık olarak 2003:012012:12 dönemini kapsayacak şekilde Word DataBank veritabanından alınmıştır.

ER: Ekonomik risk endeksi olarak tanımlanan bu değişkenin hesaplanmasında PRS Group'tan alınan ICRG Historical Data setinden kişi başına düşen gayri safi milli hâsıla, yıllık gerçek GSMH artışı, yıllık enflasyon artış oranı, GSMH'nin yüzdesi olarak bütçe dengesi ve GSMH'nin yüzdesi olarak cari hesap değişkenleri 2003:01 2012:12 dönemini kapsayacak şekilde kullanılmıştır.

FR: Finansal risk endeksi olarak tanımlanan bu değişkenin hesaplanmasında PRS Group'tan alınan ICRG Historical Data setinden GSMH'nin yüzdesi olarak toplam diş borç, toplam mal ve hizmet ihracatının yüzdesi olarak dış borç servisi, toplam mal ve hizmet ihracatının yüzdesi olarak cari hesap, ithalatın yapıldığı aylar bazında net uluslararası likidite ve yüzde değişim değeri olarak döviz kuru kararlılığı değişkenleri 2003:01-2012:12 dönemini kapsayacak şekilde kullanılmıştır.

PR: Politik risk endeksi olarak tanımlanan bu değişkenin hesaplanmasında PRS Group'tan alınan ICRG Historical Data hükümetin istikrarı, sosyoekonomik durum, yatırım ortamı, iç karışıklık, dış karışıklık, yozlaşma, askeri otoritenin politikaya etkisi, dinsel gerilimler, kanun ve düzenlemeler, etnik gerilim, demokratik sorumluluklar ve bürokrasi etkisi değişkenleri 2003:01-2012:12 dönemini kapsayacak şekilde kullanılmıştır.

$I C R G$ : Ülke riski ya da komposit risk endeksi olarak tanımlanan bu değişkenin hesaplanmasında PRS Group'tan alınan ICRG Historical Data setinden ekonomik, politik ve finansal risk değişkenleri 2003:01-2012:12 dönemini kapsayacak şekilde kullanılmıştır. 
